\title{
MATHEMATICAL TRAUMA STUDENTS' JUNIOR HIGH SCHOOL BASED ON GRADE AND GENDER
}

\author{
Ayu Faradillah, Leha Febriani* \\ Universitas Muhammadiyah Prof. Dr. HAMKA, Indonesia
}

\begin{tabular}{l}
\hline \hline Article Info \\
\hline Article history: \\
Received Sep 27, 2020 \\
Revised Nov 23, 2020 \\
Accepted Jan 5, 2021 \\
\hline
\end{tabular}

\section{Keywords:}

Mathematical Trauma,

Mathematics,

Rasch Model,

Trauma

\begin{abstract}
Mathematical trauma is a mental condition of students caused by experiences that make it difficult or emotionally with mathematics. This study analyzes students' trauma of mathematics based on grade and gender by using survey research methods and data processing using Winsteps. The subjects of the research were 204 students in every grade in Junior High School. The questionnaire consisted of 20 statements. This instrument was developed measuring mathematical trauma. It consisted of three indicators: difficult to adapt to the environment, saturated with the learning system that is done, and difficult to get along and organize themselves. Based on the Rasch analysis, for the item, two items (I10 and I7) are a misfit, and the rest items are fit. The items were suitable for 147 respondents (72.06\%). Based on The Wright Maps table on WinSteps, the percentage of male students who are very traumatized by mathematics is more than female students. Meanwhile, based on grade, students from grade 8 are more very traumatized by mathematics than students from grade 7 and grade 9. Furthermore, based on a questionnaire, students prefer to class condition that made very traumatized by mathematics.
\end{abstract}

Copyright (C) 2021 IKIP Siliwangi. All rights reserved.

\section{Corresponding Author:}

Leha Febriani,

Department of Mathematics Education,

Universitas Muhammadiyah Prof. Dr. HAMKA,

Jl. Tanah Merdeka No. 20, Ciracas, Jakarta Timur, DKI Jakarta 13830, Indonesia

Email: Lehafebri21@gmail.com

\section{How to Cite:}

Faradillah, A., \& Febriani, L. (2021). Mathematical trauma students' junior high school based on grade and gender. Infinity, 10(1), 53-68.

\section{INTRODUCTION}

The trauma is an emotional response because of anxiety from bad experiences that have occurred and give a negative impact on individual personality and social environment (Clayton, 2020; Luyten et al., 2020; Williams et al., 2018). In the US, 40\% of students have experienced of traumatic stress in their lives according to The National Child Traumatic Stress Network (Brunzell, Stokes, \& Waters, 2016). Experiences that make trauma easier to remember, if always remembered it, it will have an impact on daily life that causes stress. A negative impact on emotional that allows increased problems in schools if students are have high levels of stress and trauma (Mendelson, Tandon, O’Brennan, Leaf, \& Ialongo, 2015). School is a potentially critical place to provide services to overcome the trauma experienced by children (Chafouleas, Koriakin, Roundfield, \& Overstreet, 2019). Trauma is related to students' understanding and occurs when students has a very difficult experience or 
emotional or mathematical disturbances, by allowing them to have a long-term influence on life, including the lives of students as students and users of mathematics (Lange \& Meaney, 2011). In fact, there are many students who do not like mathematics, the biggest factor is because students feel mathematics is a difficult subject, therefore many students avoid mathematics.

There are three indicators of learning trauma, which are difficult to adapt to the environment, saturated with the learning system that is done, and difficult to get along and manage themselves (Romli, 2017). One potential trauma experienced by students is when math problems that require completion steps are made homework, especially if the student is having difficulty with mathematics (Lange \& Meaney, 2011). Students who have problems with number symbols usually have difficulties with mathematics (Jordan \& Levine, 2009). Mathematics is closely related to numbers, so if students have difficulties with numbers, it will also have an impact on their mathematical abilities.

Mathematics is considered as the basis of science and technology. It is a very important subject in high school, therefore every country applies mathematics to support the development of science and technology (Faradillah, 2018). Mathematics has a very important role in daily life, because there are many activities that involve mathematics. Mathematics has an important role in the process of developing human thought because mathematics and reasoning are inseparable (Crosby et al., 2018).

Measure mathematical trauma in some research are (Crosby et al., 2018; Lange \& Meaney, 2011; Mendelson et al., 2015; Proulx, 2019). The results of the above research are school discipline practices can greatly influence adolescent development. Students who have trauma can still have good social relationships and success if the school environment provides to support these students (Crosby et al., 2018). Some of the causes of students experiencing mathematical trauma arising from homework, namely if procedural mathematics is made homework, if students cannot do the calculations they need, and if schools only provide mathematics learning limited just to practicing multiplication or calculation (Lange \& Meaney, 2011). Which can influence emotions and increase problems in the school are when adolescents who have high levels of stress and trauma (Mendelson et al., 2015). Mathematical activities carried out to find exploratory relationships between representations which then make a conclusion. The mental state of students towards mathematics in ongoing mathematics activities deserves attention for the scope of mathematics education (Proulx, 2019).

Mathematics is one of the subjects that is considered difficult because of its abstract concept so that many students in secondary school consider mathematics to be a difficult, boring, and uninterest subject. This has become one of the triggers for some students get low scores in mathematics in their school. In school, challenge for students is learning mathematics (Daud et al., 2020). Mathematics ability of male is higher than female in grade 7 and grade 9 (Petersen \& Hyde, 2017). Several topics can be related to gender to be research material because it is interesting problems in educational studies. Male students have a higher psychological interest in mathematics than female students (Chen, Yang, \& Hsiao, 2016). Men have higher self-concept than women in some other research results (Peteros et al., 2019). No one has discussed based on research related to trauma mathematics using the Rasch model for mathematical trauma of students in junior high school based on grade and gender.

This research is aimed to analyzing item difficulties mathematical trauma students' junior high school based on grade and gender. Finally, new studies are produced to enrich innovation in the world of mathematics education which can then be utilized by all groups. 


\section{METHOD}

This study used survey method for data collection. The instrument consisted of 20 statements (Table 1). It was validated by two validators, including lecturers and teacher, where it had gone through a revision process and was declared eligible for testing by both validators. Subject of the research was 204 students of every grade in Junior High School. This instrument was developed measuring mathematical trauma. Mathematical trauma divided into three indicators, including difficulty to adapt to the environment, saturated with the learning system that is done, and difficult to get along and organize themselves. Data collected from the results of questionnaire distribution were evaluated by Rasch Mode. The answer choices are guided by a Likert scale with four answer options in the form of "strongly agree (SA)", "agree (A)", "disagree (D)", and "strongly disagree (SD)".

Table 1. Instrument of survey

\begin{tabular}{llllll}
\hline \multirow{2}{*}{ No } & \multirow{2}{*}{ Statements } & \multicolumn{4}{c}{ Answer } \\
\cline { 2 - 5 } & & SA & A & D & SD \\
\hline
\end{tabular}

Difficult to adapt to the environment.

I1 If the class conditions are quiet and comfortable, then I can study with focus.

I2 The sound of vehicles outside the school distracts concentration while studying in class.

I3 Noise from other classes disturbs concentration while studying in class.

I4 The classroom atmosphere became tense when I started math class which made me nervous.

I5 It is easier for me to understand math when studying outside school hours.

Saturated with the learning system that is done.

I6 The teacher appoints the same student every time he gives a math question/problem.

I7 I like it when teachers use math software when teaching in class.

I8 I feel sleepy while doing math problems.

I9 I am bored when the teacher teaches mathematics with the lecture method.

I10 I am excited when teachers do learning with a group discussion system.

I11 I like it when I have an assignment to make math teaching aids.

I12 I like it when teachers use teaching aids when teaching mathematics. 


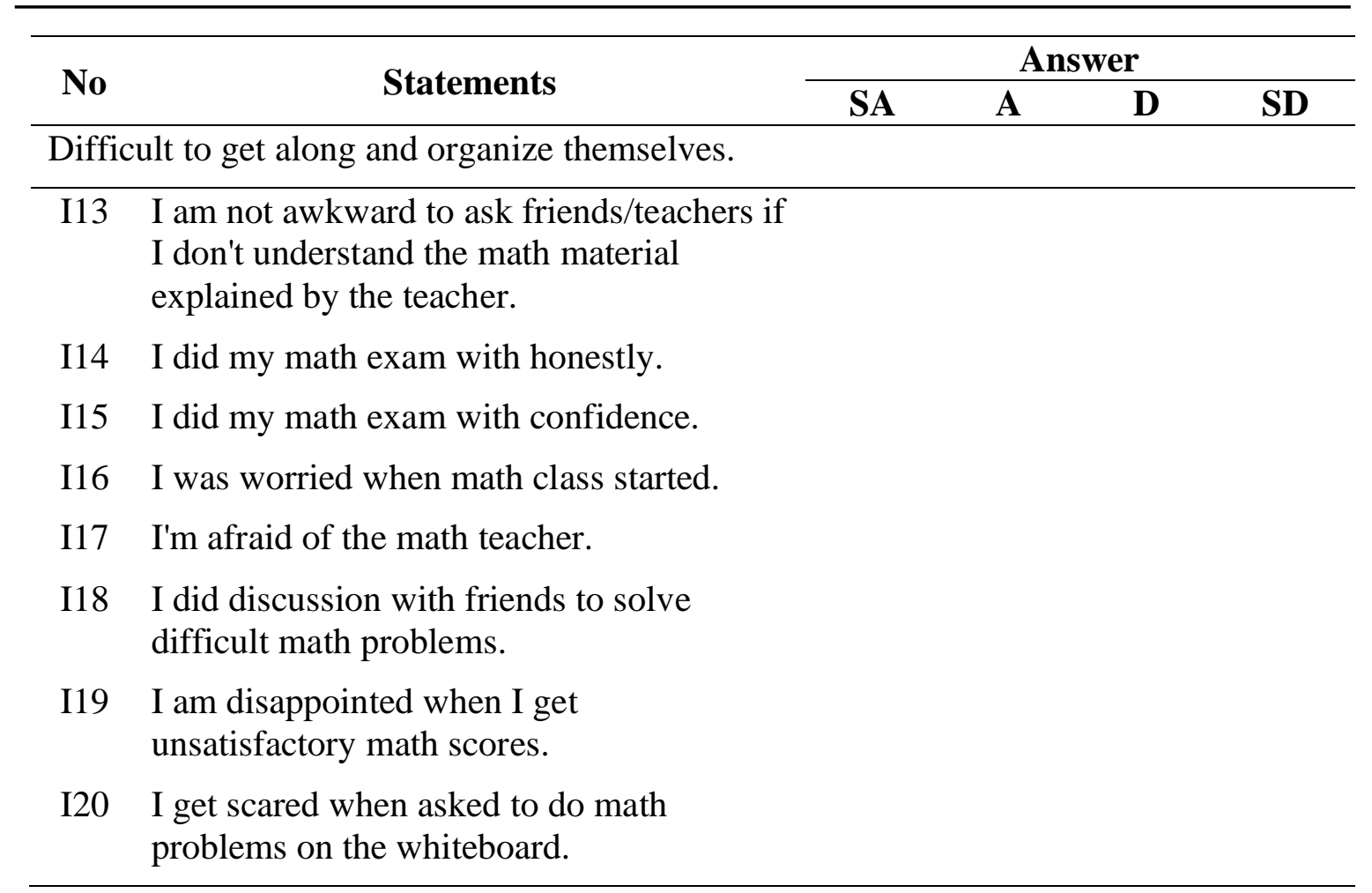

The Rasch Model made it possible to change ordinal data from questionnaires to interval data (Nguyen \& Ng, 2014; Park \& Liu, 2019; Setiawan, Panduwangi, \& Sumintono, 2018). The Rasch model shows diagnostic information for improving the quality of instruments and benefits to scaling and interpretation (Willse, 2017). Some of the advantages of the Rasch model include being able to predict missing dates and data bias, measuring based on the logit scale, knowing student distribution, converting ordinal data into intervals, and showing wright maps of variables (Ölmez \& Ölmez, 2019; Soeharto \& Rosmaiyadi, 2018). Not only using the Rasch model for evaluation but also to determine the validity and reliability of the mathematical trauma questionnaire by using WinSteps software as well as determining the validity and reliability of the data for the Cronbach's Alpha $(\alpha)$ reliability evaluation (Osman et al., 2016). This study categorized the subject's demographic data into two parts, namely grade and gender.

Table 2. Reliability in rasch analysis (Sumintono \& Widhiarso, 2014)

\begin{tabular}{ccc}
\hline Statistics & Fit Indices & Interpretation \\
\hline Cronbach's alpha (KR-20) & $<0.5$ & Low \\
& $0.5-0.6$ & Moderate \\
& $0.6-0.7$ & Good \\
& $0.7-0.8$ & High \\
& $>0.8$ & Very High \\
\hline Item and Person Reliability & $<0.67$ & Low \\
& $0.67-0.80$ & Sufficient \\
& $0.81-0.90$ & Good \\
& $0.91-0.94$ & Very Good \\
& $>0.94$ & Excellent \\
\hline
\end{tabular}




\begin{tabular}{|c|c|c|}
\hline Statistics & Fit Indices & Interpretation \\
\hline Item and Person Separation & & $\begin{array}{l}\text { High separation value indicates that } \\
\text { the instruments has a good quality } \\
\text { since it can identify the group of item } \\
\text { and respondent. }\end{array}$ \\
\hline
\end{tabular}

According to Sumintono and Widhiarso (2014) on Table 2, for establishing the reliability from the Rasch Model consist by three fit indices criteria which are Cronbach's alpha, item and person reliability, and item and person separation.

Table 3. The summary of instrument statistics

\begin{tabular}{ccccc}
\hline & Mean & Separation & Reliability & Cronbach's $\boldsymbol{\alpha}$ \\
\hline Person & 0.04 & 1.05 & 0.53 & 0.53 \\
Item & 0.21 & 8.84 & 0.99 & \\
\hline
\end{tabular}

Table 3 shows a summary of statistical instruments, including reliability of person and items. The result shows that measurement is reliable. The results of the analysis are person-output data that shows the suitability of the respondent and item-output data shows the suitability of the instrument. (Ölmez \& Ölmez, 2019). The separation coefficient is a very important addition to evaluating the function of a measurement instrument.

Coefficient of the Cronbach's $\alpha$ has a value of 0.59 , it means moderate. The reliability results of the items with a score of 0.99 show that the items used have a very good level of reliability and the 20 items measured have a separation with a score of 8.84 (rounded to 9) which means it is divided into 9 groups of items from which can be easily considered to the most difficult to considered (Setiawan et al., 2018).

Table 4. Fit indices for item fit and person fit (Sumintono \& Widhiarso, 2014)

\begin{tabular}{lc}
\hline \multicolumn{1}{c}{ Statistics } & Fit Indices \\
\hline Outfit Mean Square Values (MNSQ) & $0.5-1.5$ \\
Outfit Z-Stardarized Values (ZSTD) & $-2.0-+2.0$ \\
Point Measure Correlation (PTMEA-CORR) & $0.4-0.85$ \\
\hline
\end{tabular}

Table 4 show three criteria can used for assessing the item fit, which are Outfit Mean Square Values (MNSQ), Outfit Z-Standarized Values (ZSTD), and Point Mesure Correlation (PTMEA-CORR). Item fit can inform that the item is functioning normally to supposed measurements, meanwhile if the item shows misfit it is indicated that the respondents had a misconception to the item. Three criteria above can also used for assessing the person fit (Sumintono \& Widhiarso, 2014). So, researcher can find out the items and persons are fit or misfit.

The MNSQ shows a measure of randomness which is the amount of distortion in the measurement system. Expected values are between $0.5-1.5$; if the value is less than that value indicates the data overfit the model; while a greater value indicates the data underfit the model. The ZSTD is the t-test for the hypothesis of the suitability of the data to the model, the result is a z-value which is the unit deviation (Sumintono \& Widhiarso, 2014). 
Table 5. The value of person cronbach's alpha (KR-20), person reliability, item reliability, person separation, and item separation

\begin{tabular}{lc}
\hline \multicolumn{1}{c}{ Statistics } & Value \\
\hline Cronbach's alpha (KR-20) & 0.59 \\
Person Reliability & 0.53 \\
Item Reliability & 0.99 \\
Person Separation & 1.05 \\
Item Separation & 8.84 \\
\hline
\end{tabular}

Table 5 shows the value for Cronbach's alpha (KR-20), Person Reliability, Item Reliability, Person Separation, and Item Separation based on the Rasch analysis in WinSteps. When the value of person reliability is less than 0.67, it is "low" (Table 2). Based on Table 5 , the value of Person Reliability is 0.53 with the Person Separation value of 1.05. According to Table 1, an item reliability which is higher than 0.94 is interpreted as "excellent". In this study, the value for item reliability is 0.99 with an item separation value of 8.84 . Moreover, the instrument has a "moderate" reliability if the value of the Cronbach's alpha (KR-20) between $0.5-0.6$ (Table 2) and in Table 5, the value of Cronbach's alpha (KR-20) is 0.59.

\section{RESULTS AND DISCUSSION}

\subsection{Results}

\subsubsection{Item Fit}

Item fit can inform that the item is functioning normally to supposed measurements, meanwhile if the item shows misfit it is indicated that the respondents had a misconception to the item. Any item that fails to fulfill these three criteria (Outfit MNSQ, Outfit ZSTD, and PTMEA-CORR) needs to be improved or modified to ensure the quality and suitability of the item (Saidi \& Siew, 2019). Researcher can find out the items are fit or misfit.

Table 6. Misfit order of the items

\begin{tabular}{ccccc}
\hline Item & MEASURE & $\begin{array}{c}\text { Outfit MNSQ } \\
(\mathbf{0 . 5}-\mathbf{1 . 5})\end{array}$ & $\begin{array}{c}\text { Outfit ZSTD } \\
(\mathbf{- 2 . 0}-\boldsymbol{+ 2 . 0})\end{array}$ & $\begin{array}{c}\text { PTMEA-CORR } \\
(\mathbf{0 . 4}-\mathbf{0 . 8 5})\end{array}$ \\
\hline I10 & -1.15 & $\mathbf{1 . 7 3}$ & $\mathbf{6 . 3 1}$ & $\mathbf{0 . 0 5}$ \\
I7 & -0.08 & $\mathbf{1 . 5 8}$ & $\mathbf{5 . 1 4}$ & $\mathbf{0 . 1 3}$ \\
I19 & -1.26 & 1.28 & $\mathbf{2 . 6 8}$ & $\mathbf{0 . 2 0}$ \\
I9 & 1.00 & 1.23 & $\mathbf{2 . 4 2}$ & $\mathbf{0 . 3 1}$ \\
I17 & 0.08 & 1.15 & 1.52 & 0.50 \\
I6 & 0.21 & 1.14 & 1.42 & $\mathbf{0 . 3 0}$ \\
I18 & -.1 .07 & 1.09 & 0.94 & $\mathbf{0 . 1 9}$ \\
I1 & -2.04 & 0.95 & -0.44 & $\mathbf{0 . 3 2}$ \\
I5 & 0.56 & 0.97 & -0.34 & $\mathbf{0 . 3 5}$ \\
I20 & 0.99 & 0.97 & -0.31 & 0.40 \\
I8 & 0.77 & 0.92 & -0.88 & 0.64 \\
I16 & 0.40 & 0.91 & -0.95 & 0.57 \\
I13 & -0.80 & 0.83 & -1.81 & $\mathbf{0 . 3 6}$ \\
\hline
\end{tabular}




\begin{tabular}{ccccc}
\hline Item & MEASURE & $\begin{array}{c}\text { Outfit MNSQ } \\
(\mathbf{0 . 5}-\mathbf{1 . 5})\end{array}$ & $\begin{array}{c}\text { Outfit ZSTD } \\
(\mathbf{- 2 . 0}-\boldsymbol{+ 2 . 0})\end{array}$ & $\begin{array}{c}\text { PTMEA-CORR } \\
(\mathbf{0 . 4}-\mathbf{0 . 8 5})\end{array}$ \\
\hline I15 & -0.41 & 0.83 & -1.80 & 0.46 \\
I3 & 1.45 & 0.83 & -1.98 & $\mathbf{0 . 0 6}$ \\
I11 & 0.22 & 0.83 & -1.82 & $\mathbf{0 . 2 7}$ \\
I14 & -0.34 & 0.80 & $\mathbf{- 2 . 2 5}$ & 0.42 \\
I4 & 0.86 & 0.79 & $\mathbf{- 2 . 4 5}$ & 0.59 \\
I12 & -0.75 & 0.77 & $\mathbf{- 2 . 3 9}$ & $\mathbf{0 . 3 1}$ \\
I2 & 1.34 & 0.69 & $\mathbf{- 3 . 9 4}$ & $\mathbf{0 . 2 0}$ \\
\hline
\end{tabular}

Table 6 shows based on the value of Outfit MNSQ, Outfit ZSTD, and PTMEACORR for misfit order of the items. There are some bold numbers, its indicate that items failed to fulfill the criteria suggested by (Sumintono \& Widhiarso, 2014). It is known that items I10 and I7 are misfit because its failed to fulfill the three criteria suggested by (Sumintono \& Widhiarso, 2014), items I10 and I7 should be changed. Meanwhile, there are five items (I17, I20, I8, I16, and I15) that fulfilled the three criteria suggested by (Sumintono \& Widhiarso, 2014), while the rest fulfilled at least one of the three criteria and should be retained.

\subsubsection{Person Fit}

The information of the person fit also provided by the Rasch analysis. Person fit can identify by Rasch Model based on the unusual response pattern. For example, the unusual patterns that are detected by Rasch analysis suggests that the student may not seriously when answering the items (Boone, 2016). According to Saidi and Siew (2019), 'MEASURE', Outfit MNSQ, and Outfit ZSTD are the criteria for assessing person fit or misfit.

Table 7. Misfit order of the person

\begin{tabular}{ccccc}
\hline Person & Total Score & MEASURE & $\begin{array}{c}\text { Outfit MNSQ } \\
(\mathbf{0 . 5}-\mathbf{1 . 5})\end{array}$ & $\begin{array}{c}\text { Outfit ZSTD } \\
(\mathbf{- 2 . 0}-\mathbf{+ 2 . 0})\end{array}$ \\
\hline 160PC & 59 & 1.77 & 4.28 & 6.21 \\
138PC & 61 & 1.98 & 3.35 & 4.89 \\
047LA & 59 & 1.77 & 3.08 & 4.56 \\
150PC & 46 & 0.56 & 2.86 & 4.33 \\
049PA & 63 & 2.21 & 2.55 & 3.57 \\
055LA & 57 & 1.57 & 2.40 & 3.47 \\
176LC & 60 & 1.88 & 2.44 & 3.47 \\
028PA & 40 & 0.04 & 2.33 & 3.35 \\
032LA & 62 & 2.09 & 2.21 & 2.99 \\
144LC & 58 & 1.67 & 2.07 & 2.82 \\
034LA & 57 & 1.57 & 2.19 & 3.06 \\
003PA & 70 & 3.14 & 2.17 & 2.44 \\
016PA & 49 & 0.82 & 2.16 & 3.05 \\
142PC & 59 & 1.77 & 2.09 & 2.83 \\
058PA & 57 & 1.57 & 1.99 & 2.65 \\
\hline
\end{tabular}




\begin{tabular}{|c|c|c|c|c|}
\hline Person & Total Score & MEASURE & $\begin{array}{c}\text { Outfit MNSQ } \\
(0.5-1.5)\end{array}$ & $\begin{array}{c}\text { Outfit ZSTD } \\
(-2.0-+2.0)\end{array}$ \\
\hline $123 \mathrm{LB}$ & 61 & 1.98 & 1.94 & 2.48 \\
\hline 013LA & 59 & 1.77 & 1.97 & 2.59 \\
\hline 099LB & 49 & 0.82 & 1.89 & 2.47 \\
\hline 115LB & 58 & 1.67 & 1.83 & 2.29 \\
\hline 171PC & 58 & 1.67 & 1.73 & 2.09 \\
\hline 077PB & 52 & 1.10 & 1.75 & 2.15 \\
\hline 048LA & 56 & 1.47 & 1.72 & 2.07 \\
\hline 004PA & 55 & 1.38 & 0.48 & -2.08 \\
\hline 021LA & 52 & 1.10 & 0.48 & -2.07 \\
\hline $181 \mathrm{PC}$ & 55 & 1.38 & 0.48 & -2.06 \\
\hline 074LB & 59 & 1.77 & 0.48 & -2.01 \\
\hline 157PC & 54 & 1.28 & 0.47 & -2.11 \\
\hline 103PB & 53 & 1.19 & 0.47 & -2.16 \\
\hline 186LC & 55 & 1.38 & 0.46 & -2.16 \\
\hline 194LC & 55 & 1.38 & 0.46 & -2.16 \\
\hline 196PC & 49 & 0.82 & 0.47 & -2.14 \\
\hline 010PA & 51 & 1.00 & 0.44 & -2.28 \\
\hline $117 \mathrm{LB}$ & 60 & 1.88 & 0.45 & -2.19 \\
\hline $185 \mathrm{LC}$ & 54 & 1.28 & 0.45 & -2.22 \\
\hline $125 \mathrm{~PB}$ & 63 & 2.21 & 0.44 & -2.15 \\
\hline 017PA & 57 & 1.57 & 0.41 & -2.47 \\
\hline 064PA & 57 & 1.57 & 0.40 & -2.49 \\
\hline 012LA & 53 & 1.19 & 0.39 & -2.59 \\
\hline 024PA & 53 & 1.19 & 0.39 & -2.59 \\
\hline 029PA & 54 & 1.28 & 0.39 & -2.62 \\
\hline 137PC & 58 & 1.67 & 0.39 & -2.57 \\
\hline 197PC & 51 & 1.00 & 0.39 & -2.63 \\
\hline 081LB & 58 & 1.67 & 0.38 & -2.64 \\
\hline 070LB & 59 & 1.77 & 0.37 & -2.64 \\
\hline 147PC & 59 & 1.77 & 0.37 & -2.67 \\
\hline $156 \mathrm{PC}$ & 59 & 1.77 & 0.37 & -2.67 \\
\hline 066PB & 58 & 1.67 & 0.36 & -2.75 \\
\hline 135LC & 58 & 1.67 & 0.36 & -2.75 \\
\hline 167PC & 57 & 1.57 & 0.35 & -2.80 \\
\hline 091LB & 57 & 1.57 & 0.32 & -3.03 \\
\hline 108PB & 59 & 1.77 & 0.31 & -3.09 \\
\hline 107LB & 59 & 1.77 & 0.26 & -3.42 \\
\hline 067LB & 60 & 1.88 & 0.25 & -3.46 \\
\hline
\end{tabular}




\begin{tabular}{ccccc}
\hline Person & Total Score & MEASURE & $\begin{array}{c}\text { Outfit MNSQ } \\
(\mathbf{0 . 5}-\mathbf{1 . 5})\end{array}$ & $\begin{array}{c}\text { Outfit ZSTD } \\
\mathbf{( - 2 . 0}-\mathbf{+ 2 . 0})\end{array}$ \\
\hline 068LB & 59 & 1.77 & 0.25 & -3.55 \\
072LB & 58 & 1.67 & 0.25 & -3.58 \\
026PA & 54 & 1.28 & 0.24 & -3.70 \\
073PB & 56 & 1.47 & 0.24 & -3.65 \\
\hline
\end{tabular}

Table 7 presented the respondents (which is the students in this case), whose response was mos misfit with the Rasch Model analysis, it means their response was different from the range given by the Rasch Model. The respondents on the Table 6 were coded accordingly, the 160 was the number of respondents, $\mathrm{P}$ refers to the female while $\mathrm{C}$ was the grade 9. According to Table 7, there are 22 respondents' scored an Outfit ZSTD value greater than 2.0, it means the items was unpredictable, while 35 respondents' scored less than -2.0 , it means the items was too predictable (Sumintono \& Widhiarso, 2014). Meanwhile, the rest respondents have an Outfit ZSTD value within the acceptable range $(-2.0-2.0)$. In this study, the items were suitable for 147 respondents (72.06\%) and the analysis conducted on those respondents showed quality findings for the assessment using the Rasch analysis.

\subsubsection{The Wright Maps}

The analysis in this study was seen from two aspects, namely grade and gender. The data obtained were analysed using The Rasch Model to determine student responses based on distributed questionnaires. The Rasch model presents diagnostic information for the purpose of evaluating and improving instruments (Willse, 2017). Data were collected on the scale from 204 students from every grade in Junior High School.

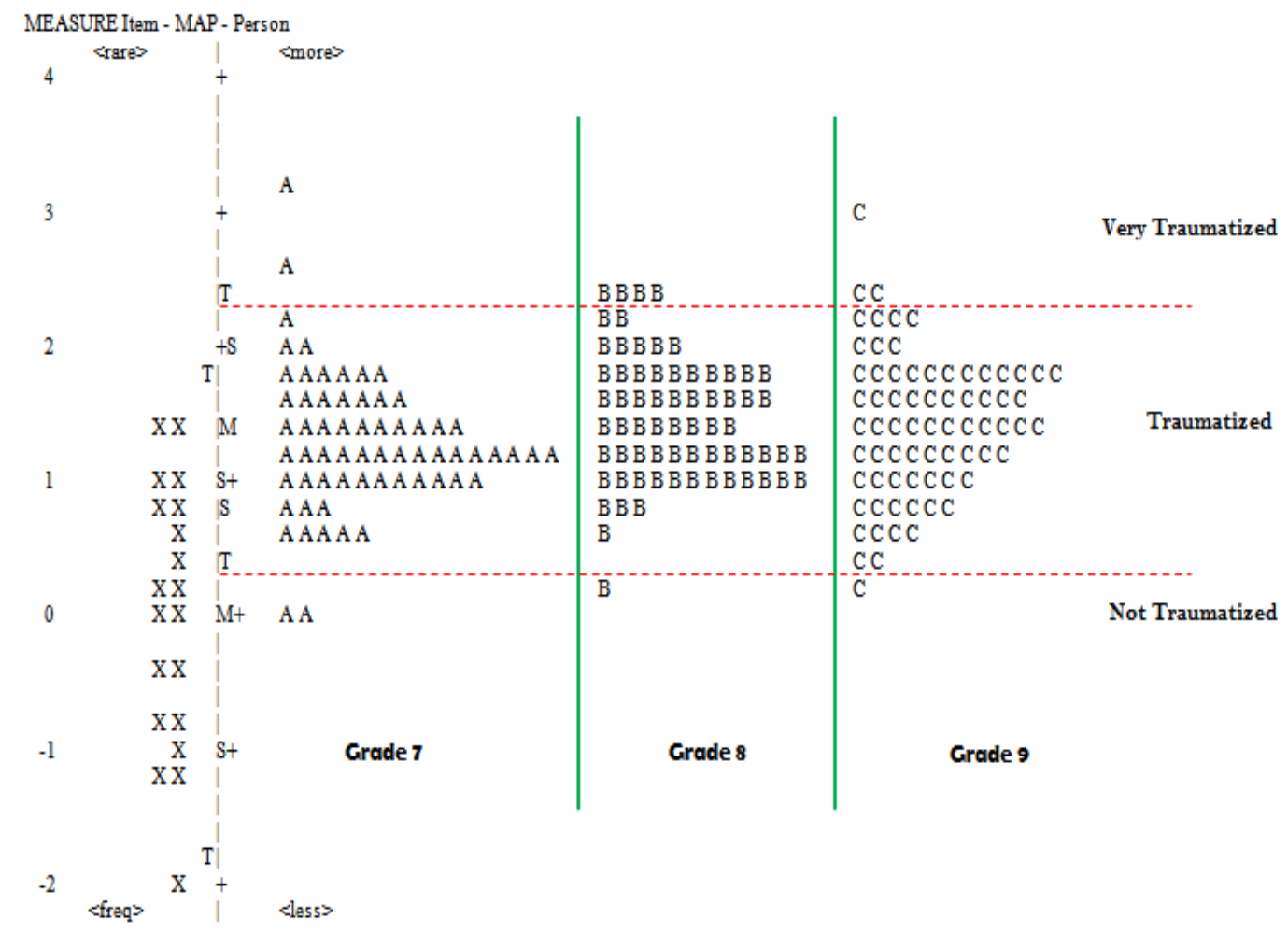

Figure 1. The wright maps of mathematical trauma based on grade 
Figure 1 students from grade 8 who were very traumatized compared to grade 7 and grade 9 , which is grade $8(5.88 \%)$, grade $9(4.17 \%)$, and grade $7(3.125 \%)$. Students in grade 7 have the lowest math anxiety (Luo, Wang, \& Luo, 2009) so they have the lowest percentage students who very traumatized. Meanwhile, abstract reasoning ability of students from grade 8 was low and should reach extended level (Kusmaryono et al., 2018) so that it makes students very traumatized by mathematics. The percentage result was calculated of every grade, not from all of the respondents.

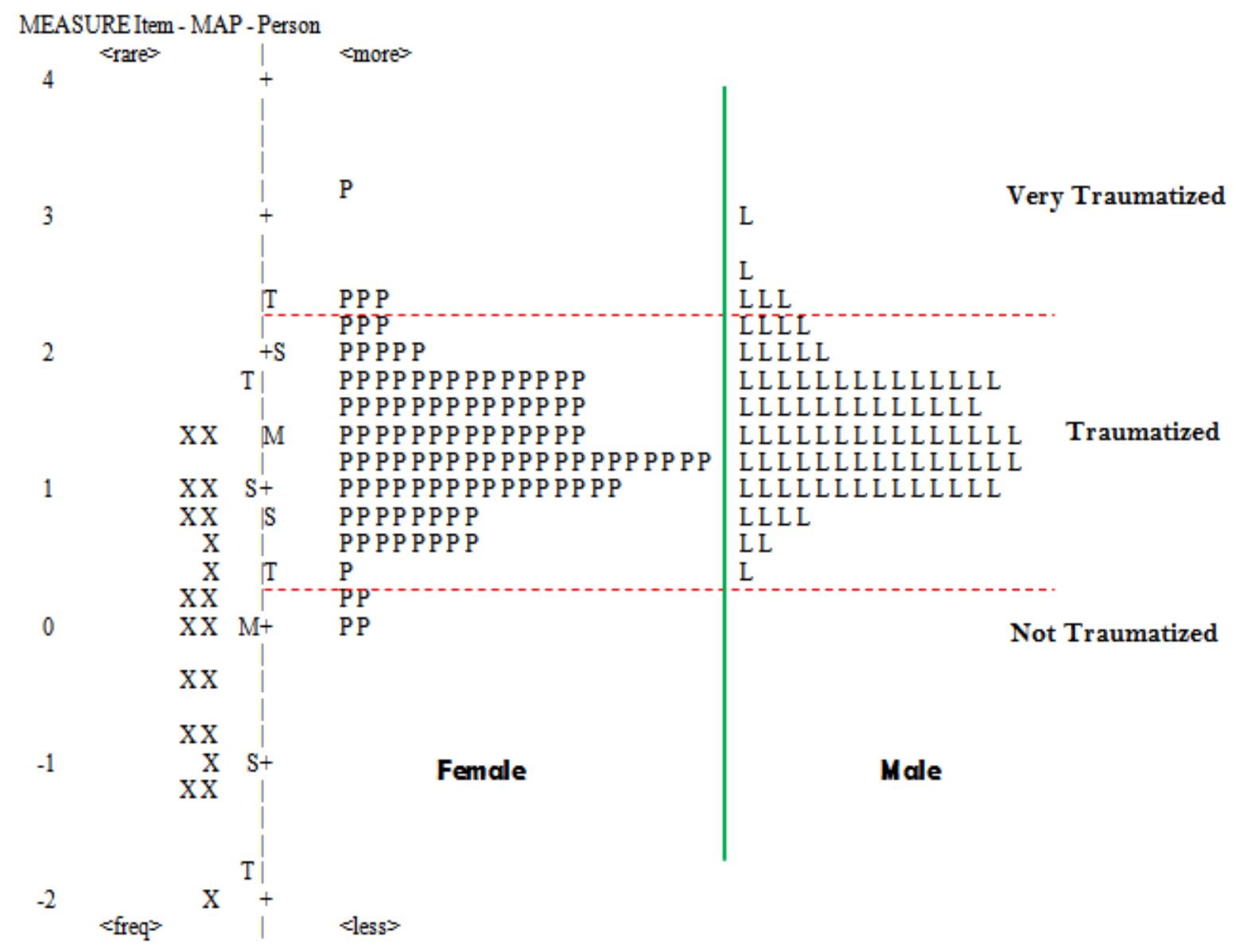

Figure 2. The wright maps of mathematical trauma based on gender

Figure 2 male students who were very traumatized compared to female students, which is male $(5.43 \%)$ and female $(3.57 \%)$. Work on mathematics for students who have good mathematics ability will easier. In mathematics, female students are better than male students (Purwasih, Anita, \& Afrilianto, 2019), so male students more trauma with mathematics than female because mathematics ability of male students are low than female students. Male students have more bad experiences with mathematics so the level of trauma is higher than female students. The percentage result was calculated of every gender, not from all of the respondents.

Table 8. Students' quantity based on level of trauma

\begin{tabular}{cc}
\hline Level of Trauma & Quantity \\
\hline Very Traumatized & 9 \\
Traumatized & 191 \\
Not Trauma & 4 \\
\hline
\end{tabular}


Table 8 shows from 204 students as subject, there are 9 students who were very traumatized, 191 students who were traumatized, and 4 students who were not traumatized. In percentage there are $4.42 \%$ for students who were very traumatized, $93.63 \%$ for students who were traumatized, and $1.96 \%$ for students who very traumatized.

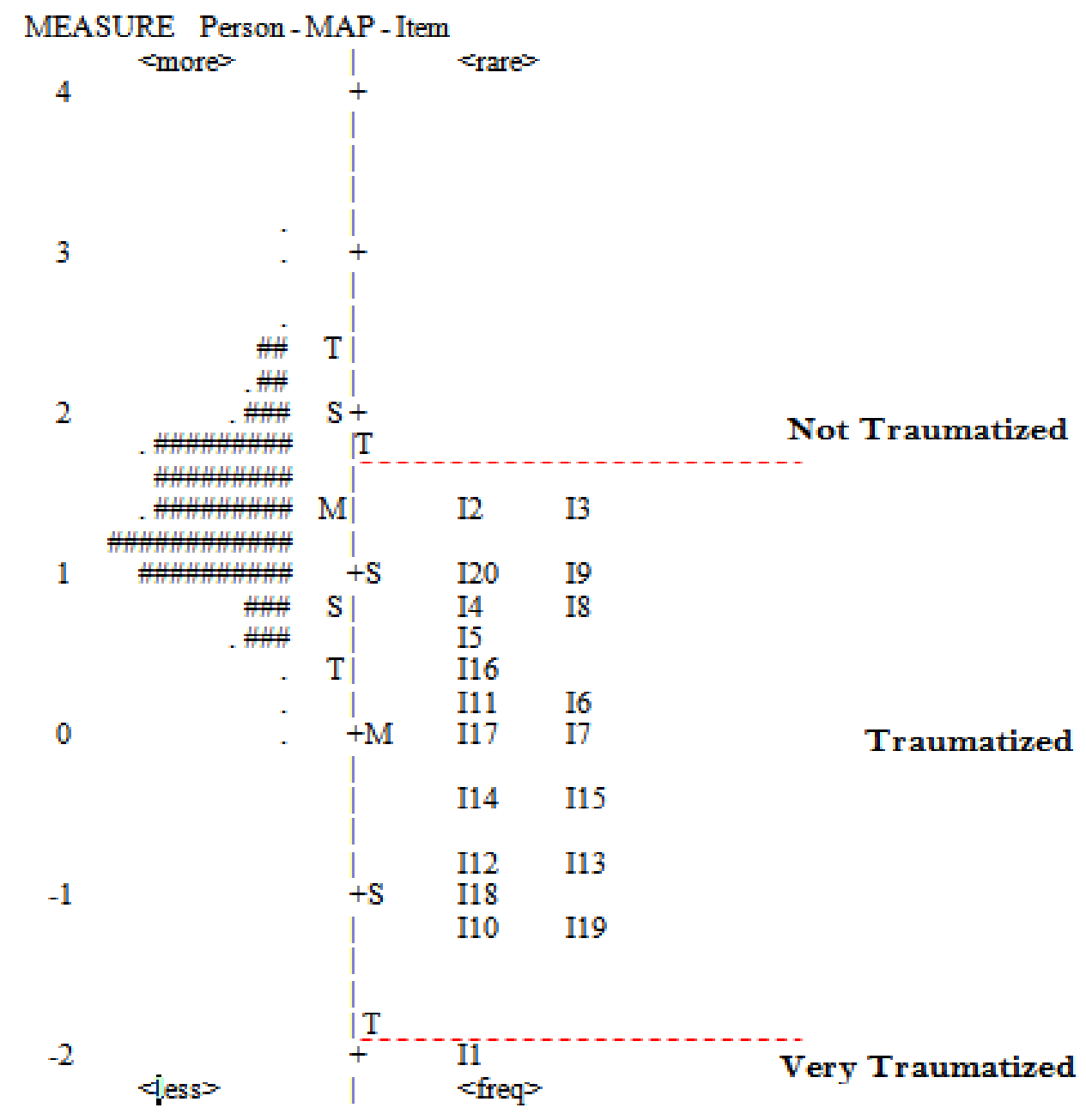

Figure 3. The wright maps of mathematical trauma questionnaire

Figure 3 shows based on the results of Wright Maps on WinSteps. Data were consisted of 20 statements from questionnaire and analyzed through WinSteps. The item that make students very traumatized by mathematics students from grade 8 who were very traumatized was "If the classroom conditions are calm and comfortable, then I can study with focus", which is 5\% of very traumatized, $95 \%$ traumatized and $0 \%$ not traumatized. Students will be more motivated to learn if the classroom conditions are conducive and comfortable (Mawardi \& Supadi, 2018). Keep the classroom climate in mind when studying is likely to increase positive outcomes for students (Barr, 2016). Class condition is one of the factors in student success in learning.

\subsection{Discussion}

Based on questionnaire result, 8 from 9 students who very traumatized (Table 8) by mathematics strongly agree with statement "I'm afraid of the math teacher" in the instrument research. Afraid is one of the characteristics of anxiety. Anxiety is an emotional response 
when experiencing frustration or conflict, so that feeling will arise through various emotions such as afraid, surprise, weakness, guilt, and feeling threatened (Aminullah, 2013; Hidayat \& Ayudia, 2019; Prahmana et al., 2019).

According to Prawirohusodo (Anita, 2014), in behavioral theory, frustration and trauma that are continuous and not handled will cause anxiety for students. If this is allowed, it will affect the psychological and emotional condition of students when studying or interacting with subjects which are a source of anxiety. Mathematics anxiety cannot be seen as a normal thing, because the inability of students to adapt to lessons causes students difficulties with mathematics which ultimately lead to low learning outcomes and achievement in mathematics.

There are several ways to reduce math anxiety for students according to Freeman (Syafri, 2017), namely: (1) Overcoming negative self-impressions of mathematics. (2) Frequently asking questions when feeling difficulties with mathematics (3) Must be brave in trying to understand mathematics because mathematics is new knowledge. (4) Not limited to one text book. (5) Creating a state of relaxation, comfort, and pleasure when learning mathematics. As for teachers, Woodard (Zakaria and Nordin, 2008) suggests several techniques that can be used to reduce math anxiety, including: (1) Creating a calm and relaxed mathematics learning environment. (2) Using cooperative groups. (3) Teaching without haste. (4) Provide additional learning, so that no student is left behind academically.

Overall, according to the analysis from the Rasch Model, the instruments has moderate Cronbach's alpha (KR-20), low Person Reliability, and excellent Item Reliability. In terms of validity, there are two items (I10 and I7) that must be changed. Meanwhile, there are five items (I17, I20, I8, I16, and I15) that fulfilled the three criteria suggested by (Sumintono \& Widhiarso, 2014), while the rest should be retained because the items fulfilled at least one item of the suitability criteria for Outfit MNSQ, Outfit ZSTD, and PTMEACORR. An item may misfit because it is difficult for the students but is unexpectedly answered correctly by poor-performing students or because it is an easy item that is unexpectedly answered incorrectly by high-performing students (Boone, 2016).

For person fit, the items were suitable for 147 respondents $(72.06 \%)$ and misfit for 57 respondents (27.94\%). From 52 respondents are misfit, there are 22 respondents' scored an Outfit ZSTD value greater than 2.0, it means the items was unpredictable, while 35 respondents' scored less than -2.0 , it means the items was too predictable (Sumintono \& Widhiarso, 2014).

\section{CONCLUSION}

According to analysis result, concluded that from 204 students consisting of every grade in Junior High School as subjects, male students and students from grade 8 more traumatized by mathematics caused by class condition that not conducive. Moreover, based on the Rasch analysis, the items I10 and I7 are misfit because its failed to fulfill the three criteria, there are Mean Square Values (MNSQ), Outfit Z-Standarized Values (ZSTD), and Point Mesure Correlation (PTMEA-CORR), items I10 and I7 should be changed. Meanwhile, there are five items (I17, I20, I8, I16, and I15) that fulfilled the criteria, while the rest fulfilled at least one of the criteria and should be retained. The items were suitable for 147 respondents $(72.06 \%)$ and the analysis conducted on those respondents showed quality findings for the assessment using the Rasch analysis. Furthermore, depend on The Wright Maps table on WinSteps, the percentage of male students who very traumatized by mathematics is more than female students. Meanwhile, based on grade, students from grade 8 are more very traumatized by mathematics than students from grade 7 and grade 9 . 
Therefore, based on questionnaire, students prefer to class condition that make very traumatized by mathematics.

\section{REFERENCES}

Aminullah, M. A. (2013). Kecemasan antara siswa smp dan santri pondok pesantren. Jurnal Ilmiah Psikologi Terapan, 1(2), 205-215.

Anita, I. W. (2014). Pengaruh kecemasan matematika (mathematics anxiety) terhadap kemampuan koneksi matematis siswa SMP. Infinity Journal, 3(1), 125-132.

Barr, J. J. (2016). Developing a Positive Classroom Climate. The IDEA Center, 61(October), $1-9$.

Boone, W. J. (2016). Rasch analysis for instrument development: why, when, and how?. CBE-Life Sciences Education, 15(4), rm4. https://doi.org/10.1187/cbe.1604-0148

Brunzell, T., Stokes, H., \& Waters, L. (2016). Trauma-informed positive education: Using positive psychology to strengthen vulnerable students. Contemporary School Psychology, 20(1), 63-83. https://doi.org/10.1007/s40688-015-0070-x

Chafouleas, S. M., Koriakin, T. A., Roundfield, K. D., \& Overstreet, S. (2019). Addressing childhood trauma in school settings: A framework for evidence-based practice. School mental health, 11(1), 40-53. https://doi.org/10.1007/s12310-0189256-5

Chen, S. C., Yang, S. J., \& Hsiao, C. C. (2016). Exploring student perceptions, learning outcome and gender differences in a flipped mathematics course. British Journal of Educational Technology, 47(6), 1096-1112. https://doi.org/10.1111/bjet.12278

Clayton, S. (2020). Climate anxiety: Psychological responses to climate change. Journal of Anxiety Disorders, 74, 102263. https://doi.org/10.1016/j.janxdis.2020.102263

Crosby, S. D., Day, A. G., Somers, C. L., \& Baroni, B. A. (2018). Avoiding school suspension: Assessment of a trauma-informed intervention with court-involved, female students. Preventing School Failure: Alternative Education for Children and Youth, 62(3), 229-237. https://doi.org/10.1080/1045988X.2018.1431873

Daud, A. S., Abd Aziz, M. K. N., Ali, W. N. A. B. W., Adnan, N. S. M., \& Embong, Z. (2020). Students' Perception in Learning Mathematics across Gender and Ethnicity. Journal of Physics: Conference Series, 1529(3), 032019. https://doi.org/10.1088/1742-6596/1529/3/032019

Faradillah, A. (2018). Analysis of mathematical reasoning ability of pre-service mathematics teachers in solving algebra problem based on reflective and impulsive cognitive style. Formatif: Jurnal Ilmiah Pendidikan MIPA, 8(2), 119-128. https://doi.org/10.30998/formatif.v8i2.2333

Hidayat, W., \& Ayudia, D. B. (2019). Kecemasan matematik dan kemampuan pemecahan masalah matematis siswa SMA. Kalamatika: Jurnal Pendidikan Matematika, 4(2), 205-214. https://doi.org/10.22236/KALAMATIKA.vol4no2.2019pp205-214

Jordan, N. C., \& Levine, S. C. (2009). Socioeconomic variation, number competence, and mathematics learning difficulties in young children. Developmental disabilities research reviews, 15(1), 60-68. https://doi.org/10.1002/ddrr.46 
Kusmaryono, I., Suyitno, H., Dwijanto, D., \& Dwidayati, N. (2018). Analysis of abstract reasoning from grade 8 students in mathematical problem solving with SOLO taxonomy guide. Infinity Journal, 7(2), 69-82. https://doi.org/10.22460/infinity.v7i2.p69-82

Lange, T., \& Meaney, T. (2011). I actually started to scream: Emotional and mathematical trauma from doing school mathematics homework. Educational Studies in Mathematics, 77, 35-51. https://doi.org/10.1007/s10649-011-9298-1

Luo, X., Wang, F., \& Luo, Z. (2009). Investigation and Analysis of Mathematics Anxiety in Middle School Students. Journal of Mathematics Education, 2(2), 12-19.

Luyten, P., Campbell, C., \& Fonagy, P. (2020). Borderline personality disorder, complex trauma, and problems with self and identity: A social-communicative approach. Journal of Personality, 88(1), 88-105. https://doi.org/10.1111/jopy.12483

Mawardi, D., \& Supadi, S. (2018). Concentration on Learning Program Development in Islamic Education. AL-HAYAT: Journal Of Islamic Education, 2(2), 213-230. https://doi.org/10.35723/ajie.v2i2.35

Mendelson, T., Tandon, S. D., O'Brennan, L., Leaf, P. J., \& Ialongo, N. S. (2015). Brief report: Moving prevention into schools: The impact of a trauma-informed schoolbased intervention. Journal of Adolescence, 43, 142-147. https://doi.org/10.1016/j.adolescence.2015.05.017

Nguyen, T., \& Ng, D. (2014). Applying the Rasch model to investigate Singapore principals' instructional leadership practices. Leading and Managing, 20(2), 1-26.

Ölmez, İ. B., \& Ölmez, S. B. (2019). Validation of the Math Anxiety Scale with the Rasch Measurement Model. Mathematics Education Research Journal,31(1), 89-106. https://doi.org/10.1007/s13394-018-0244-8

Osman, S. A., Khoiry, M. A., Rahman, N. A., Rahni, A. A. A., Mansor, M. R. A., Nordin, D., \& Johar, S. (2016). The effectiveness of industrial training from the perspective of students of the civil and structure engineering department. Journal of engineering Science and Technology, 11, 1-12.

Park, M., \& Liu, X. (2019). An investigation of item difficulties in energy aspects across biology, chemistry, environmental science, and physics. Research in Science Education, 1-18. https://doi.org/10.1007/s11165-019-9819-y

Peteros, E., Gamboa, A., Etcuban, J. O., Dinauanao, A., Sitoy, R., \& Arcadio, R. (2019). Factors affecting mathematics performance of junior high school students. International Electronic Journal of Mathematics Education,15(1), em0556. https://doi.org/10.29333/iejme/5938

Petersen, J. L., \& Hyde, J. S. (2017). Trajectories of self-perceived math ability, utility value and interest across middle school as predictors of high school math performance. Educational Psychology, 37(4), 438-456. https://doi.org/10.1080/01443410.2015.1076765

Prahmana, R. C. I., Sutanti, T., Wibawa, A. P., \& Diponegoro, A. M. (2019). Mathematical anxiety among engineering students. Infinity Journal, 8(2), 179-188. https://doi.org/10.22460/infinity.v8i2.p179-188 
Proulx, J. (2019). Mental mathematics under the lens: Strategies, oral mathematics, enactments of meanings. The Journal of Mathematical Behavior, 56, 100725. https://doi.org/10.1016/j.jmathb.2019.100725

Purwasih, R., Anita, I. W., \& Afrilianto, M. (2019). Junior high school students' mathematical creative thinking ability based on gender differences in plane and solid geometry subjects. Journal of Physics: Conference Series, 1315(1), 012073. https://doi.org/10.1088/1742-6596/1315/1/012073

Romli, M. E. (2017). Upaya konselor untuk mengatasi trauma di kalangan mahasiswa. PROCEEDING IAIN Batusangkar, 1(1), 171-175.

Saidi, S. S., \& Siew, N. M. (2019). Reliability and validity analysis of statistical reasoning test survey instrument using the rasch measurement model. International Electronic Journal of Mathematics Education, 14(3), 535-546. https://doi.org/10.29333/iejme/5755

Setiawan, B., Panduwangi, M., \& Sumintono, B. (2018). A Rasch analysis of the community's preference for different attributes of Islamic banks in Indonesia. International Journal of Social Economics. 45(12), 1647-1662. https://doi.org/10.1108/IJSE-07-2017-0294

Soeharto, S., \& Rosmaiyadi, R. (2018). The Analysis of students' higher order thinking skills (HOTS) in Wave and Optics Using IRT with Winstep Software. Journal of Educational Science and Technology (EST), 1(1), 145-150.

Sumintono, B., \& Widhiarso, W. (2014). Aplikasi model Rasch untuk penelitian ilmu-ilmu sosial (edisi revisi). Cimahi: Trim Komunikata Publishing House.

Syafri, F. S. (2017). Ada Apa dengan Kecemasan Matematika?. Journal of Medives: Journal of Mathematics Education IKIP Veteran Semarang, 1(1), 59-65.

Williams, M. T., Metzger, I. W., Leins, C., \& DeLapp, C. (2018). Assessing racial trauma within a DSM-5 framework: The UConn Racial/Ethnic Stress \& Trauma Survey. Practice Innovations, 3(4), https://psycnet.apa.org/doi/10.1037/pri0000076

242.

Willse, J. T. (2017). Polytomous Rasch models in counseling assessment. Measurement and Evaluation in Counseling and Development, 50(4), 248-255. https://doi.org/10.1080/07481756.2017.1362656

Zakaria, E., \& Nordin, N. M. (2008). The effects of mathematics anxiety on matriculation students as related to motivation and achievement. Eurasia Journal of Mathematics, Science and Technology 27-30. https://doi.org/10.12973/ejmste/75303 
